IRSTI 06.52.01

UDC 331.538 .2

https://doi.org/10.46914/1562-2959-2020-1-4-76-80

D.I. ZAKIROVA, ${ }^{1}$

$\mathrm{PhD}$.

Turan University ${ }^{1}$

\title{
SYSTEMS APPROACH IN THE RESEARCH OF HUMAN POTENTIAL
}

\begin{abstract}
The wealth of a nation in an information society is expressed in intelligence, creative ideas, information, the mass of knowledge, intellect, in other words, in the objects of accumulated intellectual capital. The growing role of education and science, the strengthening of the values of intellectual activity within the national economy contribute to the formation and improvement of the human potential of society, being the essential factors of socio-economic progress. Human potential development is one of the most important tasks facing any country. The competitive advantages of the economy, the possibilities of its modernization are directly determined by the accumulation in the country and the employed human potential. After all, the possibilities and limits of necessary changes in social development are determined by people with their professional experience, education and qualifications. This article discusses a systematic approach to the study of human potential. Using a systematic approach allows establishing the integrity and boundaries of human potential, to determine the composition and structure of its elements. Within the framework of system approach, the elements of human potential are classified according to some characteristics: subjects of human potential, the content of knowledge as the basis of human potential, the possibility of fixing knowledge, its alienation and reproduction, the form of interaction within the system of human potential.
\end{abstract}

Key words: human potential, system approach, information economy, education, innovative education, intellectual capital, knowledge content.

A variety of approaches characterizes the genesis of scientific ideas and views on human potential. At the same time, there is no holistic concept of human potential. Many theoretical aspects of human potential remain insufficiently studied, such as the essence, structure, features of its reproduction, the specificity of economic relations in the sphere of action.

Human potential as a complex education must, first of all, be investigated within the framework of a systematic approach. Systemic knowledge of the object of study is based on the identification of the main thing in it. It sets the system properties of the object. It based on the study of the connections of this whole with other objects and phenomena, as well as connections within the system. However, it is not always possible to select an element from the system. Often, it can only be learned by interacting with other elements. These interactions carry information about the elements of the system. Probably, the era of an indeed systems approach in economic research has now begun.

A systemic vision of society is characteristic of the methodological position of K. Marx, who considered social history as a natural change of socio-economic formations, saw an organic whole in the social system.

The methodological principle denoted by the term "system modelling" is used by institutionalists who see in the national economy a living, developing organism, where everything is interconnected by circular causality. System modelling introduces new factors and regroups old ones, which makes it possible to consider the economic system in dynamics.

Each system is influenced by a higher-level system, affecting the goals, objectives, volumes, methods and directions of resource use, etc. At the same time, the system interacts with lower-order systems. It expresses the systemic and communicative aspect of consistency. The interconnection of components allows the presence of spatial, temporal, functional, genetic, etc. in the system connections. The most stable, system-forming connections form the structure of the system and ensure the orderliness and organization of its components.

Any complex system can be represented by a vast (even infinite) number of structural invariants that reflect different aspects and properties of the system. The structure and various levels of the hierarchy of interrelationships of different quality and therefore, contradictory components of the system reflects the organization of the system, which predetermines the systemic and structural aspect of consistency. The direction of movement of the system is predetermined by the goal, usually set by the superior system. 
As F. Engels noted, in nature (since we leave aside the reverse influence of man on it) only blind, unconscious forces act on one another, in the interaction of which general laws are manifested. There is nowhere a conscious, desired goal here: not in the countless seeming accidents visible on the surface, nor in the final results that confirm the existence of a pattern within these accidents. On the contrary, in history, there are people gifted with consciousness, acting deliberately or under the influence of passion, striving for specific goals. Nothing is done here without a conscious intention, without the desired goal.

All the listed signs of the system are inherent in human potential. Human potential understood in an expansive meaning encompasses the totality of production factors, systematizing them according to the social essence, while simultaneously entering the production system as its leading, acting component. From the standpoint of this approach, in our opinion, human potential is a complex system with different material and non-material embodiment. Systemic analysis of potential realizes the idea of socio-economic unity, reality, organically combining natural conditions and production resources, technical and economic progress, social and personal factors (knowledge, education, moral values, culture). This integrity is based on the mechanisms of socialization, culture and consciousness, the intelligence of individuals, which become the source of self-development of society [1].

Human potential, as one of the components of the economic system, mediating various kinds of connections and relationships, allows building around itself a variety of system structures in which it will act as their subsystem or element [2].

Human potential is a complex formation and can be expressed through many of its sides. It becomes possible to present each such description as a system with a particular structure and mechanism of relations between its elements, that is, a set of structural and functional invariants of the system reflecting economic, organizational, institutional and other aspects of human potential.

Due to the component structure, the system as a complex object allows many dismemberments and, therefore, can be described through combinations of various components united by links. In this case, the external visible on the surface of the diversity is a consequence of the internal, essential diversity.

Since some systems with different connections can exist around the object under study, the systems approach does not exist in the form of a rigorous methodological concept. However, it carries a heuristic principle, which contains the experience, intuition and individuality of the researcher. At the same time, it remains unclear what is the system-forming principle of human potential, concentrating its nature in itself, what is the direction of its movement, development, transformation.

Systemic cognition of human potential involves identifying the determinants of a given system, leading its elements to be organized into a system; establishing the laws of the functioning and development of this system. The disclosure of the systemic properties of the potential, that is, the properties acquired through the system, is based on the choice of the "unit of the system". It allows fixing the integral properties of the system, its structure and dynamics [3]. Such a core, which predetermines the logical structure of the system and its properties, can rightfully be called a system-forming element that carries the critical characteristic of integrity. Finding the objective basis of the whole, its central part, the variety of connections of the whole serves as a reliable basis for obtaining that wealth of theoretical concepts, which is capable of reflecting the whole in its diversity and complexity.

The information economy requires a philosophy and methodology for managing education because this process is associated with the development of creative skills and skills in the information society. The main component of this process is the creative abilities of the individual, free from the dogmatic influence of stereotypes. The transition of humanity to the scientifically grounded principle of the creative community of individuals is determined by two main trends in the evolution of social consciousness. The first one is connected with the complication of the structures (complexification) of a living organism, during which the human brain appeared. This factor determined not only the evolution of a living organism but also the evolution of technologies of a social, technical and economic nature. In social terms, this led to the development of a complex network of relationships between people and to their unification into social institutions with different structures and economic mechanisms of management. The second is determined by the dematerialization (reduction of organic matter) of natural productive forces. Information (energy-information) technologies are replacing energy-intensive and material-intensive technologies. It changes the paradigm of education. 
Back in 1994, they put forward a new paradigm of innovative education. The authors of the concept defined innovative education as a system that contributes to the development of a person's abilities to navigate in new conditions, to adapt to them [4].

Note that although the definition of the new paradigm of education as innovative determines the direction of change in the content and forms of the educational process, it does not establish interdependent functional systems of the behaviour of the person himself in the learning process with the social and economic environment. Modern concepts of higher education do not consider the student himself as the bearer of potential means of achieving professional results of activity flowering, maturity, strength and power in achieving professional knowledge.

Creativity, productive knowledge, should become a methodology of cognition and educational environment. A person in the education system should be considered not only as a subject of the educational process but also as an individual and personality, bringing his characteristic information parameters into the system, changing its stable state. For education systems, the prognostic direction of development is the transition from training specialists of an industrial society to an informational one. This transition is characterized by the fact that workers are employed only where human judgment, judgment and creativity are needed; the ability to innovate becomes the main thing. First of all, this concerns the issues of methodology and methodology as scientific, cognitive means, prerequisites and principles of organizing activities, including the conceptual apparatus, approaches, methods and techniques that determine the modern worldview of phenomena and processes by describing their information aspects. Knowledge and information about them become the basis of national wealth.

A qualitatively new situation in education requires a new quality of methodology and management methods, which is the task of system analysis. The most crucial step in the development of education management methodology is a systemic understanding of the process of human education, the system of principles of human development as a complex self-developing natural system. Within the framework of education, the problem of competition becomes very urgent. It is associated with the study of the positive and negative experience of educational activities. In the system of educational and innovative services strategy and tactics for the development of human potential are developed [5].

The use of a systematic approach in shaping the quality of the information and educational environment requires a comprehensive analysis of internal and external conditions. This analysis refers to the problem of innovations, organizational technologies of management of educational institutions. The recognition of the social responsibility of the results of the activities of educational structures for the socio-economic and political transformations in the country requires leaders at all levels to use, first of all, the scientific and intellectual potential of the higher school itself. The most obvious and discussed problems are the problems of the consequences of the economic, cultural and political arrangement of society, and as derivatives of them - the problems of education: methodological, financial and economical; problems of the content and quality of education; technological; organizational; problems of accessibility and cost of education; problems of the mentality of the teaching staff. Human potential as a source of new ideas, concepts, knowledge and skills determines the principle of continuous education and an endless stream of consumers of educational products.

The main obstacle to the application of new technologies in the education of human potential is the existing organizational, functional and scientific and educational potential of educational institutions and management of the educational process. Also, the market for educational services is characterized by wave fluctuations, the relationship between supply and demand, manifested in the alternation of relative excess and shortage of qualified specialists with higher education. Such fluctuations are manifested in an immature, unstable market for educational services. The cyclical nature of the development of the education services market is due to the total impact on it of a complex of factors of a general economic nature. They are changes in the socio-economic structure of society; fluctuations in the general economic and sectoral environment and related structural changes in the national economy; the state of the national education system; the situation on the labour market. Now the education market has come close to a situation where the volume of supply has begun to exceed the previously dominant significant demand. A differentiated demand for educational services has taken shape; the infrastructure of the educational services market has been formed.

Thus, we see that in the conditions of the formation of the information economy, human potential, being modified, forms a complex system that has not yet been sufficiently studied by economic 
science. Theoretical knowledge of human potential is at a stage when it is possible to give a complete scientific substantiation of the new processes occurring in it only based on the latest technologies of economic theory, including information theory of economics, theories of economic development, socio-economic transformations and other concepts.

\title{
LIST OF LITERATURE
}

1 Кравченко Л.А. Сущность и составляющие развития человеческого потенциала // Научный вестник: финансы, банки, инвестиции. - 2018. - № 3(44): https://cyberleninka.ru/article/n/suschnost-isostavlyayuschie-razvitiya-chelovecheskogo-potentsiala (дата обращения: 05.11.2020).

2 Ромащенко Т.Д., Титова О.В., Кисова А.Е. Человеческий потенциал в системе факторов экономического роста // Современная экономика: проблемы и решения. - 2014. - № 9(57). - С. 106-114.

3 Прангишвили И.В. Системный подход и общесистемные закономерности. - М.: СИНТЕГ, 2000.

4 Струк Е.Н. Инновационная парадигма образования в изменяющемся мире // Экономика образования. - 2012. - № 1: https://cyberleninka.ru/article/n/innovatsionnaya-paradigma-obrazovaniya-vizmenyayuschemsya-mire (дата обращения: 05.11.2020).

5 Закирова Д.И. Human potential as a factor of innovative development // Вестник университета Туран. - 2019. - № 2(82). - С. 102-106.

\section{LIST OF LITERATURE}

1 Kravchenko L.A. Sushchnost' i sostavlyayushchie razvitiya chelovecheskogo potentsiala // Nauchnyi vestnik: finansy, banki, investitsii. - 2018. - № 3(44): https://cyberleninka.ru/article/n/suschnost-isostavlyayuschie-razvitiya-chelovecheskogo-potentsiala (data obrashcheniya: 05.11.2020).

2 Romashchenko T.D., Titova O.V., Kisova A.E. Chelovecheskii potentsial v sisteme faktorov ekonomicheskogo rosta // Sovremennaya ekonomika: problemy i resheniya. - 2014. - № 9(57). - S. 106-114.

3 Prangishvili I.V. Sistemnyi podkhod i obshchesistemnye zakonomernosti. - M.: SINTEG, 2000.

4 Struk E.N. Innovatsionnaya paradigma obrazovaniya $\mathrm{v}$ izmenyayushchemsya mire // Ekonomika obrazovaniya. - 2012. - № 1: https://cyberleninka.ru/article/n/innovatsionnaya-paradigma-obrazovaniya-vizmenyayuschemsya-mire (data obrashcheniya: 05.11.2020).

5 Zakirova D.I. Human potential as a factor of innovative development // Vestnik universiteta Turan. 2019. - № 2(82). - S. 102-106.

Д.И. ЗАКИРОВА, ${ }^{1}$

$\mathrm{PhD}$.

«Тұран» университеті ${ }^{1}$

\section{АДАМИ ӘЛЕУЕТТІ ЗЕРТТЕУДЕГІ ЖУЙЕЛІ ТӘСІЛ}

\begin{abstract}
Андатпа
Ақпараттық қоғамдағы ұлттың байлығы интеллект, идеялар, ақпарат, бұқаралық білім, басқаша айтқанда, жинақталған зияткерлік капитал объектілерінде көрінеді. Білім мен ғылым рөлінің артуы, халық шаруашылығындағы зияткерлік қызметтің маңыздылығының артуы әлеуметтік-экономикалық прогрестің маңызды факторлары бола отырып, қоғамның адами әлеуетін қалыптастыруға және жетілдіруге ықпал етеді. Адами әлеуетті дамыту - еліміздің алдында тұрған аса маңызды міндеттердің бірі. Экономиканың бәсекелік артықшылықтары, оны жаңғырту мүмкіндіктері елде жинақталумен және жұмылдырылған адами әлеуетпен тікелей айқындалады. Бұл әлеуметтік дамудың қажетті өзгерістерінің мүмкіндіктері мен шекараларын анықтайтын білімі, біліктілігі, кәсіби тәжірибесі бар адамдар. Осы мақалада адами әлеуетті зерттеудегі жүйелі тәсіл қарастырылған. Жүйелік тәсілді қолдану адами әлеуеттің тұтастығы мен шекараларын анықтауға, оның элементтерінің құрамы мен құрылымын анықтауға мүмкіндік береді. Осы тәсіл аясында адами әлеуеттің элементтері бірқатар белгілер бойынша жіктеледі: білімді бекіту мүмкіндігі, оларды иеліктен шығару және көбейту, адами әлеует жүйесіндегі өзара әрекеттесу формасы, адами әлеуеттің негізі ретінде білім мазмұны, қаржылық нәтиже, кәсібилік, нормативтік құжаттар, адами әлеуеттің субъектілері.
\end{abstract}

Тірек сөздер: адами әлеует, жүйелі көзқарас, ақпараттық экономика, жүйе, білім беру, инновациялық білім беру, зияткерлік капитал, білім мазмұны. 
Д.И. ЗАКИРОВА, ${ }^{1}$

$\mathrm{PhD}$.

Университет «Туран» ${ }^{1}$

\title{
СИСТЕМНЫЙ ПОДХОД В ИССЛЕДОВАНИИ ЧЕЛОВЕЧЕСКОГО ПОТЕНЦИАЛА
}

\begin{abstract}
Аннотация
В современном информационном обществе богатство нации выражается в информации, креативных идеях, массовости знаний, интеллекте, иначе говоря, в объектах накопленного интеллектуального капитала. Усиление значения интеллектуальной деятельности в экономике, а также возрастание роли образования и науки способствуют формированию и совершенствованию человеческого потенциала общества, что является важнейшим фактором социально-экономического прогресса. Развитие человеческого потенциала - одна из приоритетных задач, стоящих перед любой страной. Конкурентные преимущества экономики, возможности ее модернизации напрямую определяются накоплением в стране и задействованным человеческим потенциалом. Ведь возможности и границы необходимых перемен общественного развития определяются людьми с их профессиональным опытом, образованием и квалификацией. В настоящей статье рассмотрен системный подход в исследовании человеческого потенциала. Использование системного подхода позволяет установить целостность и границы человеческого потенциала, определить состав и структуру его элементов. В рамках системного подхода по ряду признаков классифицированы элементы человеческого потенциала: субъекты человеческого потенциала, содержание знаний как основы человеческого потенциала, возможность фиксации знаний, их отчуждения и воспроизводства, форма взаимодействия внутри системы человеческого потенциала.
\end{abstract}

Ключевые слова: человеческий потенциал, системный подход, информационная экономика, образование, инновационное образование, интеллектуальный капитал, содержание знаний. 